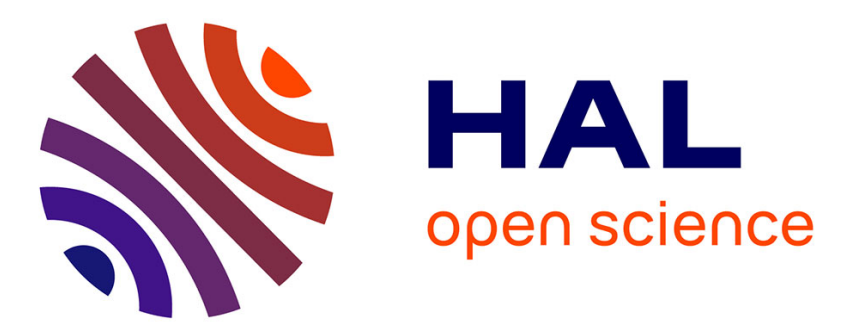

\title{
Altitude Distribution of Stratospheric NO3: 2. Comparison of Observations With Model
}

Michel Pirre, Radiela Ramaroson, Jean-Pierre Naudet, Pierre Rigaud

\section{To cite this version:}

Michel Pirre, Radiela Ramaroson, Jean-Pierre Naudet, Pierre Rigaud. Altitude Distribution of Stratospheric NO3: 2. Comparison of Observations With Model. Journal of Geophysical Research: Atmospheres, 1989, 94 (D5), pp.6383-6388. 10.1029/JD094iD05p06383 . insu-02879599

\section{HAL Id: insu-02879599 \\ https://hal-insu.archives-ouvertes.fr/insu-02879599}

Submitted on 24 Jun 2020

HAL is a multi-disciplinary open access archive for the deposit and dissemination of scientific research documents, whether they are published or not. The documents may come from teaching and research institutions in France or abroad, or from public or private research centers.
L'archive ouverte pluridisciplinaire HAL, est destinée au dépôt et à la diffusion de documents scientifiques de niveau recherche, publiés ou non, émanant des établissements d'enseignement et de recherche français ou étrangers, des laboratoires publics ou privés. 


\title{
Altitude Distribution of Stratospheric $\mathrm{NO}_{3}$ 2. Comparison of Observations With Model
}

\author{
Michel Pirre, ' Radiela Ramaroson, Jean-Pierre Naudet, and Pierre Rigaud
}

Laboratore de Physique et Chimie de l'Environnement, CNRS, Orléans, France

\begin{abstract}
The theoretical calculations of the altitude distribution of $\left|\mathrm{NO}_{3}\right|$, made with a time-dependent zero-dimensional model taking into account the accepted photochemistry of the stratosphere, are compared with the measurements presented in a companion paper. The concentration of $\left|\mathrm{NO}_{3}\right|$ is shown to be strongly dependent on the ozone concentration and temperature. These parameters were measured and used as fixed data in the model. The results show excellent consistency between theory and measurements.
\end{abstract}

\section{INTRODUCTION}

Ground-based measurements of the $\mathrm{NO}_{3}$ column content at different locations [Norton and Noxon, 1986] in some cases show large discrepancies between the measurements and the theoretical calculations, assuming the recommended photochemistry for $\mathrm{NO}_{3}$. To explain such discrepancies, Norton and Noxon [1986] suggest an unknown scavenging process that would exist mainly at high latitudes in the northern hemisphere. The effects of this scavenger process should be observed at mid-latitudes, especially for air parcels coming from the north. Similar discrepancies have not been observed in Antarctica [Sanders et al., 1987]. As already mentioned by Naudet et al. [1981], the discrepancy was also not observed between the altitude distribution measured from a balloon platform at mid-latitudes and the theoretical calculations; nevertheless, some important changes have appeared since the publication of their paper in both the photoabsorption cross sections for $\mathrm{NO}_{3}$ around 662 $\mathrm{nm}$ and the rate constant involving $\mathrm{N}_{2} \mathrm{O}_{5}$ and $\mathrm{NO}_{3}$. Naudet et al. [this issue] mention that the changes in the photoabsorption cross sections lead to a decrease of the retrieved $\mathrm{NO}_{3}$ concentrations. The aim of this paper is to reexamine the consistency between the theoretical calculations, using the rate constants of DeMore et al. [1985] and the new $\mathrm{NO}_{3}$ concentrations measured during five stratospheric balloon flights Naudet et al., [this issue].

\section{THEORY}

The $\mathrm{NO}_{3}$ concentration at night is currently assumed to be governed by three reactions [Herman, 1979], whose rate constants are $k_{1}, k_{2}$, and $k_{3}$ :

$$
\begin{array}{cc}
\mathrm{NO}_{2}+\mathrm{O}_{3} \rightarrow \mathrm{NO}_{3}+\mathrm{O}_{2} & \left(k_{1}\right) \\
\mathrm{NO}_{3}+\mathrm{NO}_{2} \stackrel{\mathrm{M}}{\rightarrow} \mathrm{N}_{2} \mathrm{O}_{5} & \left(k_{2}\right) \\
\mathrm{N}_{2} \mathrm{O}_{5} \stackrel{\mathrm{M}}{\rightarrow} \mathrm{NO}_{2}+\mathrm{NO}_{3} & \left(k_{3}\right)
\end{array}
$$

Based on DeMore et al. [1985],

$$
k_{1}=1.2 \times 10^{-13} \exp (-2450 / T) \mathrm{cm}^{3} \mathrm{~s}^{-1}
$$

'Also at Université d'Orléans, Orléans, France.

Copyright 1989 by the American Geophysical Union.

Paper number 89JD00175.

0148-0227/89/89JD-00175\$05.00

$$
k_{2} \mathrm{M}=\frac{k_{20} \mathrm{M}}{1+k_{20} \mathrm{M} / k_{2 x}} \times 0.6^{\left\{1+\left[\log \left(k_{20} \mathrm{M} / k_{2 \alpha}\right)\right]^{3}\right\}^{-1}} \mathrm{~cm}^{3} \mathrm{~s}^{-1}
$$

where

$$
\begin{gathered}
k_{20}=2.2 \times 10^{-30}(T / 300)^{-4.3} \mathrm{~cm}^{6} \mathrm{~s}^{-1} \\
k_{2 x}=1.5 \times 10^{-12}(T / 300)^{-0.5} \mathrm{~cm}^{3} \mathrm{~s}^{-1} \\
k_{3} \mathrm{M}=\frac{k_{2} \mathrm{M}}{K} \\
K=1.52 \times 10^{-27} \exp (11,153 / T) \mathrm{cm}^{3}
\end{gathered}
$$

and $T$ is the temperature.

The $\mathrm{NO}_{3}$ time constant to reach the equilibrium, at night, is equal to $1 / k_{2} \mathrm{M}\left|\mathrm{NO}_{2}\right|$, where $\left|\mathrm{NO}_{2}\right|$ is the concentration of the $\mathrm{NO}_{2}$ specie. Assuming realistic values of $\left|\mathrm{NO}_{2}\right|$ [see Naudet et al., this issue, table 7] and temperature measured on September 24, 1985 (see Table 1), $\tau$ is 40 min at $38 \mathrm{~km}$ and $10 \mathrm{~min}$ at $32 \mathrm{~km}$. This equilibrium is therefore reached during the night. So if $\left|\mathrm{O}_{3}\right|,\left|\mathrm{NO}_{2}\right|$, and $\left|\mathrm{N}_{2} \mathrm{O}_{5}\right|$ are assumed to be constant, then $\left.\mid \mathrm{NO}_{3}\right\rfloor$ may be written as

$$
\left|\mathrm{NO}_{3}\right|=\frac{k_{1}}{k_{2} \mathrm{M}}\left|\mathrm{O}_{3}\right|+\frac{k_{3}}{k_{2}} \frac{\left|\mathrm{N}_{2} \mathrm{O}_{5}\right|}{\left|\mathrm{NO}_{2}\right|}
$$

Full model calculations show that $\left|\mathrm{O}_{3}\right|$ is not varying during the night but that $\left|\mathrm{NO}_{2}\right|$ is slightly decreasing and that $\left|\mathrm{N}_{2} \mathrm{O}_{5}\right|$ is increasing. Therefore $\left|\mathrm{NO}_{3}\right|$ does not reach a constant value and (1) is just an approximation. Nevertheless, this relation may be used to estimate the evolution of $\left|\mathrm{NO}_{2}\right|$ and $\left|\mathrm{N}_{2} \mathrm{O}_{5}\right|$. This evolution is governed, using (1), by

$$
\begin{aligned}
& \frac{d\left|\mathrm{NO}_{2}\right|}{d t}=-2 k_{1}\left|\mathrm{O}_{3}\right|\left|\mathrm{NO}_{2}\right| \\
& \frac{d\left|\mathrm{~N}_{2} \mathrm{O}_{5}\right|}{d t}=k_{1}\left|\mathrm{O}_{3}\right|\left|\mathrm{NO}_{2}\right|
\end{aligned}
$$

Assuming that $\left|\mathrm{N}_{2} \mathrm{O}_{5}\right|$ is negligible at the beginning of the night, these equations can be solved easily, leading to $\left|\mathrm{NO}_{2}\right|$ and $\left|\mathrm{N}_{2} \mathrm{O}_{5}\right|$ as a function of the time and using (1), to $\left|\mathrm{NO}_{3}\right|$ as

$$
\left|\mathrm{NO}_{3}\right|=\frac{k_{1}}{k_{2} \mathrm{M}}\left|\mathrm{O}_{3}\right|+\frac{k_{3}}{2 k_{2}}\left\{\exp \left[2 k_{1}\left|\mathrm{O}_{3}\right|\left(t-t_{0}\right)\right]-1\right\}
$$

where $t_{0}$ is the time at sunset, and $t$ is the time of the measurement. 
TABLE 1. Temperature Used in Calculations

\begin{tabular}{ccccccc}
\hline & & \multicolumn{5}{c}{ Temperature, K } \\
\cline { 3 - 7 } $\begin{array}{c}\text { Pressure, } \\
\text { Hpa }\end{array}$ & $\begin{array}{c}\text { Approximate } \\
\text { Altitude, km }\end{array}$ & $\begin{array}{c}\text { Sept. 12, } \\
1980\end{array}$ & $\begin{array}{c}\text { Sept. 18, } \\
1981\end{array}$ & May 3, 1982 & $\begin{array}{c}\text { Sept. 14, } \\
1983\end{array}$ & $\begin{array}{c}\text { Sept. 24, } \\
1985\end{array}$ \\
\hline 40 & 22 & 220 & $\ldots$ & 220 & 219 & $\ldots$ \\
25 & 25 & 224 & $\ldots$ & 222 & 222 & 220 \\
16 & 28 & 227 & $\ldots$ & 225 & 225 & 226 \\
12 & 30 & 231 & $\ldots$ & 230 & 228 & 230 \\
9 & 32 & 234 & 232 & 236 & 230 & 232 \\
6.6 & 34 & 237 & 239 & 246 & 235 & 237 \\
5 & 36 & 241 & 245 & 254 & 238 & 242 \\
3.8 & 38 & 245 & 250 & 259 & 241 & 248 \\
\hline
\end{tabular}

Compared with the results of the full photochemical model described later, the errors on the results obtained with (3) at $38 \mathrm{~km}$ are $25 \%$ at $2100 \mathrm{LT}$ and $2 \%$ at $0300 \mathrm{LT}$. At $30 \mathrm{~km}$ the errors are lower than $1 \%$ for the same times. This relation is used later to discuss the sensitivity of $\left|\mathrm{NO}_{3}\right|$ to the atmospheric parameters. Nevertheless, the full photochemical model has been used to compare the theoretical calculation and the measurements.

Notice that $\left|\mathrm{NO}_{3}\right|$ is independent of $\left|\mathrm{NO}_{2}\right|$, after relation (3). This is because we have assumed that $\left|\mathrm{NO}_{3}\right|$ is given by (1). It is clear that if $\left|\mathrm{NO}_{2}\right|$ was much lower than the values used (see, for example, Table 7 of Naudet et al., [this issue]), (1) would be a very poor approximation and (3) would not be valid. Model calculations confirm that $\left|\mathrm{NO}_{3}\right|$ is almost independent of $\left|\mathrm{NO}_{2}\right|$. It is shown that decreasing $\left|\mathrm{NO}_{2}\right|$ by $50 \%$ at $38 \mathrm{~km}$ leads to a $28 \%$ decrease of $\left|\mathrm{NO}_{3}\right|$ at $2100 \mathrm{LT}$ but only to a $3 \%$ decrease at $0100 \mathrm{LT}$ and a decrease of $1.5 \%$ at $0300 \mathrm{LT}$. At $30 \mathrm{~km}$ the same decrease in $\left|\mathrm{NO}_{2}\right|$ leads to a decrease in $\left|\mathrm{NO}_{3}\right|$ which is lower than $1 \%$ at 2100,0100 , and 0300 LT.

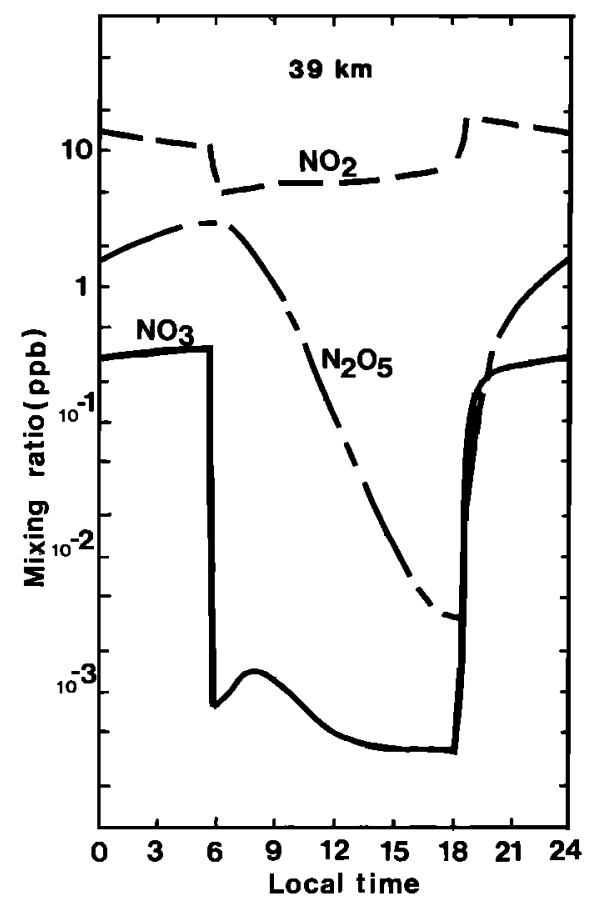

Fig. 1. Diurnal variations of the mixing ratio of $\mathrm{NO}_{2}, \mathrm{~N}_{2} \mathrm{O}_{5}$, and $\mathrm{NO}_{3}$, computed with the zero-dimensional model (see text) for September 24, 1985, at $39 \mathrm{~km}$.

\section{Sensitivity of the Concentration of $\mathrm{NO}_{3}$ to Ozone Concentration, Temperature, and The Time Lapse Since Sunset}

In the mid-latitude stratosphere the argument of the exponential of (3) is always smaller than 1 , so the $\mathrm{NO}_{3}$ concentration is approximately proportional to the ozone concentration. Furthermore, the continuous increase in $\left|\mathrm{NO}_{3}\right|$ during the night after its rapid increase at sunset (see Figure 1) is approximately proportional to the time lapse since sunset.

The $\mathrm{NO}_{3}$ concentration is also very sensitive to the temperature. Indeed, the rate constants $k_{1}$ and $k_{3}$ are strongly temperature-dependent. Table 2 shows that an increase of $5 \mathrm{~K}$ relative to the standard temperature [Nicolet, $1978]$ leads to an increase of $35-50 \%$, depending on the altitude, in the $\mathrm{NO}_{3}$ concentration at $0300 \mathrm{LT}$. Since the measurements of $\left|\mathrm{NO}_{3}\right|$ from balloons are accurate to about $30 \%$, it is clear that temperature data should be precise in order to realistically compare the measurements with the model calculations.

\section{THE Model}

The model used is a time-dependent zero-dimensional model, well adapted to study the diurnal variations of the short-lived species in the photochemically controlled part of the stratosphere $(30-50 \mathrm{~km})$ [Ramaroson et al., 1987]. In such a model the transport term is not taken into account in the continuity equation of each species. However, the transport is implicitly taken into account, because the concentrations of the long-lived species are fixed. The values of these concentrations should be those measured at the same time and location as the concentrations of the short-lived species under study. If this is not the case, the mean values available from other observations [World Meteorological Organization (WMO), 1985] for the corresponding season and latitude are used. The long-lived species concentrations needed are $\left|\mathrm{H}_{2} \mathrm{O}\right|,\left|\mathrm{CH}_{4}\right|,|\mathrm{CO}|,\left|\mathrm{H}_{2}\right|,\left|\mathrm{NO}_{y}\right|$, and $\left|\mathrm{Cl}_{x}\right|$. The concentration of ozone can be assumed to be fixed or variable. In such a model the temperature must also be fixed.

The set of continuity equations is therefore solved for the short-lived species within the $\left|\mathrm{O}_{x}\right|,\left|\mathrm{NO}_{y}\right|,\left|\mathrm{Cl}_{x}\right|$, and $\left|\mathrm{HO}_{x}\right|$ families. The method used accurately preserves the numbers of atoms; it consists of linearizing the set of continuity equations by writing each production or loss term as

$$
k|X||Y|=k\left[\varepsilon|X|^{t}|Y|^{t+\Delta t}+(1-\varepsilon)|X|^{t+\Delta t}|Y|^{t}\right]
$$

where $k$ is the rate constant of the reaction that involves the species $X$ and $Y,|X|^{\prime}$ is the concentration of the $X$ species at 
time $t,|X|^{t+\Delta t}$ is the concentration of the same species at the next time step $t+\Delta t$, and $\varepsilon$ is a parameter fixed between 0 and 1 . Usually, a value of 0.5 optimizes the accuracy of the method, but this value must be fixed to 0 or 1 for some reactions in order to avoid the appearance of negative concentration values. Once the set of equations is linearized, it is solved using an optimized code at each time step of the integration. This time step is $\mathbf{2 0}$ min during the day and the night, and it is decreased to $1 \mathrm{~min}$ at sunset and sunrise. The model includes a full spherical geometry, the Rayleigh scattering attenuation of the solar flux, and a fixed Earth albedo. The rate constants and the photodissociation cross sections are those given by DeMore et al. [1985].

In this study the ozone concentration and the temperature have been fixed to the values measured during the experiments. For the five balloon flights in question, the ozone concentration was measured simultaneously with $\left|\mathrm{NO}_{3}\right|[\mathrm{Nau}$ det et al., this issue], while the temperature was measured either by satellites, radio soundings, or lidar, as shown in section 5 . The concentration of the long-lived species has been fixed to mean values except for $\left|\mathrm{NO}_{y}\right|$ during two flights when $\left|\mathrm{NO}_{2}\right|$ was also measured (in September 1983 and September 1985). In these cases the concentration of $\left|\mathrm{NO}_{2}\right|$ at the beginning of the night, which is approximately the $\left|\mathrm{NO}_{y}\right|$ concentration above about $33 \mathrm{~km}$, can be computed using (2a). This computation is straightforward, knowing $\left|\mathrm{O}_{3}\right|$ and assuming that $\left|\mathrm{NO}_{2}\right|$ is decreasing mainly due to its interaction with $\left|\mathrm{O}_{3}\right|$.

Figure 1 shows the diurnal variations of $\left|\mathrm{NO}_{3}\right|,\left|\mathrm{N}_{2} \mathrm{O}_{5}\right|$, and $\left|\mathrm{NO}_{2}\right|$ computed with our model in the conditions of the fifth flight (September 1985) at $39 \mathrm{~km}$.

\section{The Temperature}

As seen earlier, accurate knowledge of the temperature as a function of the altitude $(22-40 \mathrm{~km})$, at the location and time of the $\left|\mathrm{NO}_{3}\right|$ measurements, is crucial to constrain our model. The $\left|\mathrm{NO}_{3}\right|$ is measured by star occultation, therefore the concentration that is measured is mainly located close to the tangent point. This point is between 0 and $500 \mathrm{~km}$ distant from the balloon location, depending on the altitude of this tangent point.

The five flights studied in this paper took place during the nights of September 11-12, 1980, September 18-19, 1981, May 2-3, 1982, September 13-14, 1983, and September 23-24, 1985 , in France at Aire-sur-l'Adour $\left(43^{\circ} 42^{\prime} \mathrm{N}, 0^{\circ} 15^{\prime} \mathrm{W}\right)$. By means of the National Meteorological Center (NMC) data, it was possible to check that in each case the temperature did not vary by more than $\pm 2 \mathrm{~K}$ around a mean value, over a large area where the tangent points are located. Since this variation is roughly equal to the statistical uncertainty of the measurements, the knowledge of the exact location of the tangent point is not

TABLE 2. Increase in $\mathrm{NO}_{3}$ Concentration at $0300 \mathrm{LT}$ as a Function of Temperature and Altitude in Equinox Conditions

\begin{tabular}{ccccc}
\hline $\begin{array}{c}\text { Altitude, } \\
\mathrm{km}\end{array}$ & $\begin{array}{c}\left|\mathrm{NO}_{3}\right|, \\
\times 10^{7} \mathrm{~cm}^{-3}\end{array}$ & $\begin{array}{c}\left|\mathrm{NO}_{3}\right|, \dagger \\
\times 10^{7} \mathrm{~cm}^{-3}\end{array}$ & $\begin{array}{c}\Delta\left|\mathrm{NO}_{3}\right|, \\
\times 10^{7} \mathrm{~cm}^{-3}\end{array}$ & $\begin{array}{c}\Delta\left|\mathrm{NO}_{3}\right| \\
\left|\mathrm{NO}_{3}\right| \\
\%\end{array}$ \\
\hline 32 & 0.95 & 1.28 & 0.33 & 35 \\
34 & 1.23 & 1.68 & 0.45 & 37 \\
36 & 1.51 & 2.12 & 0.61 & 40 \\
38 & 1.68 & 2.83 & 0.95 & 51 \\
\hline
\end{tabular}

* Mean temperature.

$\dagger$ Mean temperature plus $5 \mathrm{~K}$.

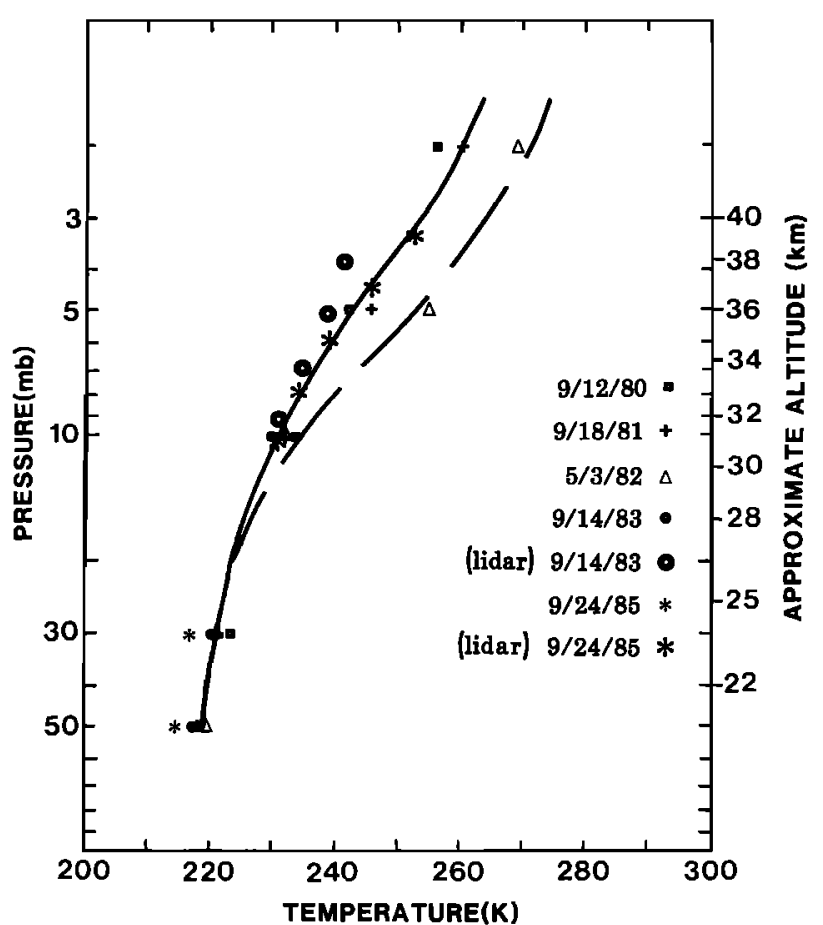

Fig. 2. Mean temperatures derived from the NMC data (see text) for the nights of September 11-12, 1980, September 18-19, 1981, May 2-3, 1982, September 13-14, 1983, and September 23-24, 1985 , and measured temperature by lidar at l'Observatoire de Haute Provence on the nights of September 13-14, 1983, and September $23-24,1985$, as a function of the pressure $P$ or the approximate altitude $h$. Also shown are the standard zonal mean temperatures for September (solid curve) and May (dashed curve). The approxımate altitudes are computed by assuming the standard zonal mean temperatures for May or September. Note that although the temperatures are very different above $10 \mathrm{mbar}$, the approximate altitudes are very close for these two months (the differences are smaller than $200 \mathrm{~m}$ ).

necessary. For two flights (September 1983 and September 1985), lidar measurements of the temperature from the Observatoire de Haute Provence are available above $30 \mathrm{~km}$ [Hauchecorne and Chanin, 1980]. The lidar measurements, which are in the area of the tangent points, were used in the theoretical calculations for these flights. For the other cases the NMC data were used. These data are given at $1200 \mathrm{UT}$, that is, approximately $1200 \mathrm{LT}$ in the south of France. Therefore the mean values between the measurements the day before and the day after the night of the $\left|\mathrm{NO}_{3}\right|$ measurements have been used. In one case (September 18-19, 1981), the measurements are not available above 10 mbar on September 18 , so the mean value between September 17 and 19 was used. Figure 2 shows NMC data and lidar measurements. Table 1 shows the data used in the calculations; the standard mean temperatures in September and May at $45^{\circ} \mathrm{N}$ are also shown in Figure 2. It can be seen that the measured temperatures are very close to the standard values and up to $10 \mathrm{~K}$ higher in May than in September, above 10 mbar.

\section{Results And Discussion}

The results of the model calculations are shown in Figures $3,4,5,6$, and 7 , as well as the measurements for the five flights. Our model has been used to compute the $\left|\mathrm{NO}_{3}\right|$ concentration above $30 \mathrm{~km}$. Below this altitude, full model calculations show that $\left|\mathrm{NO}_{3}\right|$ is given with a very good accuracy by the simple formula 


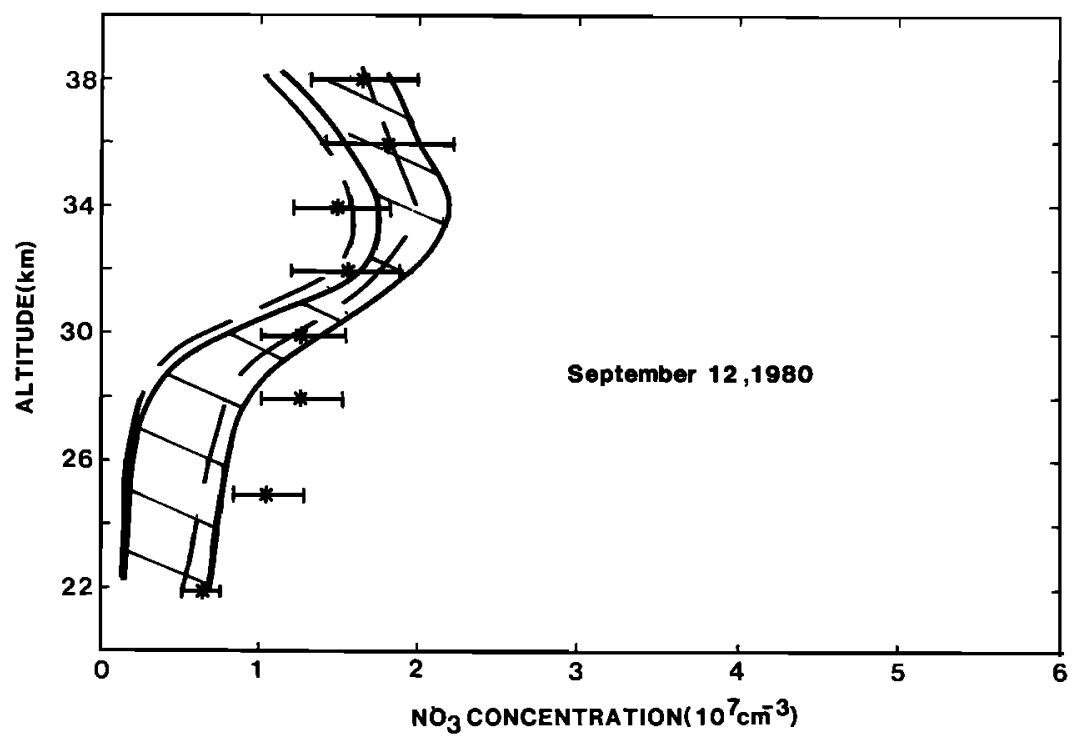

Fig. 3. Measurements of the $\mathrm{NO}_{3}$ concentration including uncertainties as a function of the altitude [after Naudet et al., this issuel, indicated by the hatched area bounded by solid curves, and the results of the theoretical calculations, indicated by asterisks with errors bars (see text) for September 12, 1980, at $0150 \mathrm{LT}$. Also shown are the measurements corrected by taking into account the dependence on the temperature of the $\left|\mathrm{NO}_{3}\right|$ absorption cross section (see text), indicated by the area bounded by dashed curves.

$$
\left|\mathrm{NO}_{3}\right|=\frac{k_{1}}{k_{2} \mathrm{M}}\left|\mathrm{O}_{3}\right|
$$

Indeed, the second term on the right-hand side of (3) is negligible because the temperature is low. This simple formula has therefore been used at these altitudes.

The uncertainties on the measurements are discussed in the companion paper [Naudet et al., this issue]. The error bars in the model calculation are computed assuming an uncertainty of $\pm 2 \mathrm{~K}$ in the temperature and an uncertainty of $\pm 10 \%$ in the ozone concentration. The minimum theoretical values shown in Figures 3-7 are obtained when temperature and ozone concentration are fixed in the model to the measured temperature $T$ (Table 1 ) minus $2 \mathrm{~K}$ and to the measured ozone concentration $\left|\mathrm{O}_{3}\right|$ [Naudet et al., this issue, Tables 3-7] minus $10 \%$, respectively. To obtain the maximum theoretical values, the temperature and the ozone concentration are fixed to $T+2 \mathrm{~K}$ and $\left|\mathrm{O}_{3}\right|+10 \%$, respectively.

The calculations and the measurements are generally in very good agreement. In particular, the large values measured in May 1982 (Figure 5) are explained by higher temperatures in May than in September (Figure 2). However, a discrepancy in the calculations exists in September 1980 between 24 and $28 \mathrm{~km}$ (Figure 3) which is not explained and could be due to the scavenging process pointed out by Norton and Noxon [1986]. Note that this discrepancy cannot be explained by a dynamical disturbance affecting $\left|\mathrm{O}_{3}\right|$ or $\left|\mathrm{NO}_{y}\right|$ because $\left|\mathrm{O}_{3}\right|$ is fixed, in the model, to the measured value and because $\left|\mathrm{NO}_{3}\right|$ is independent of $\left|\mathrm{NO}_{y}\right|$ at these altitudes. According to Norton and Noxon [1986], the effect

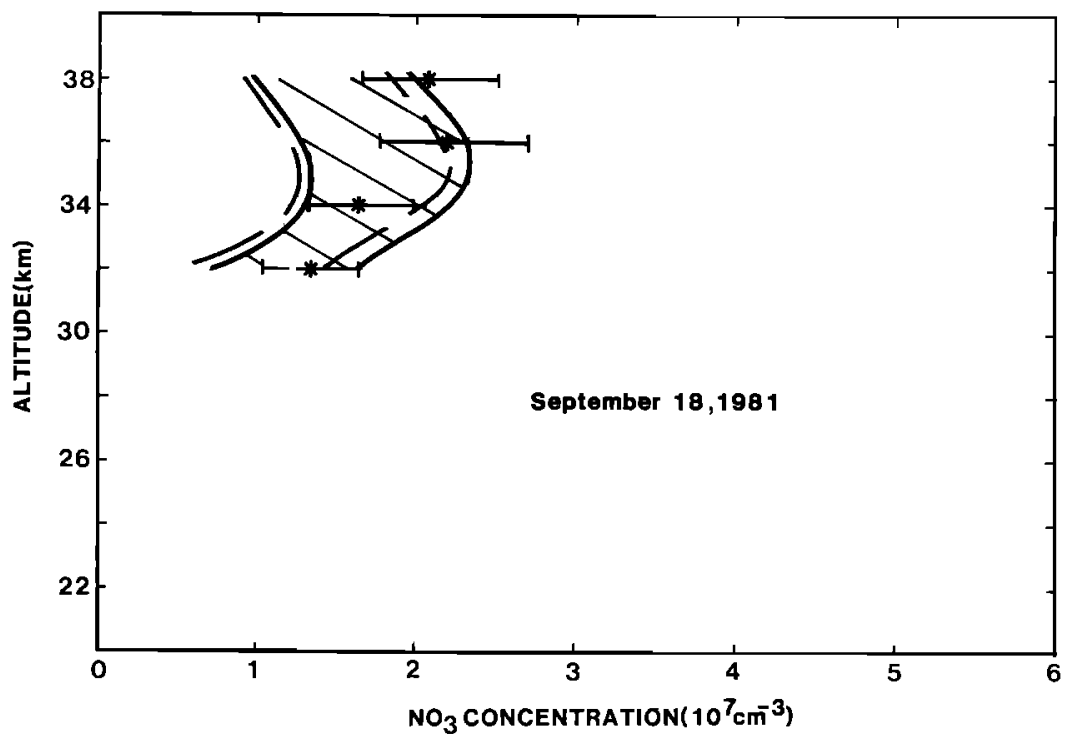

Fig. 4. Same as Figure 3, except for September 18, 1981, at 2140 LT. 


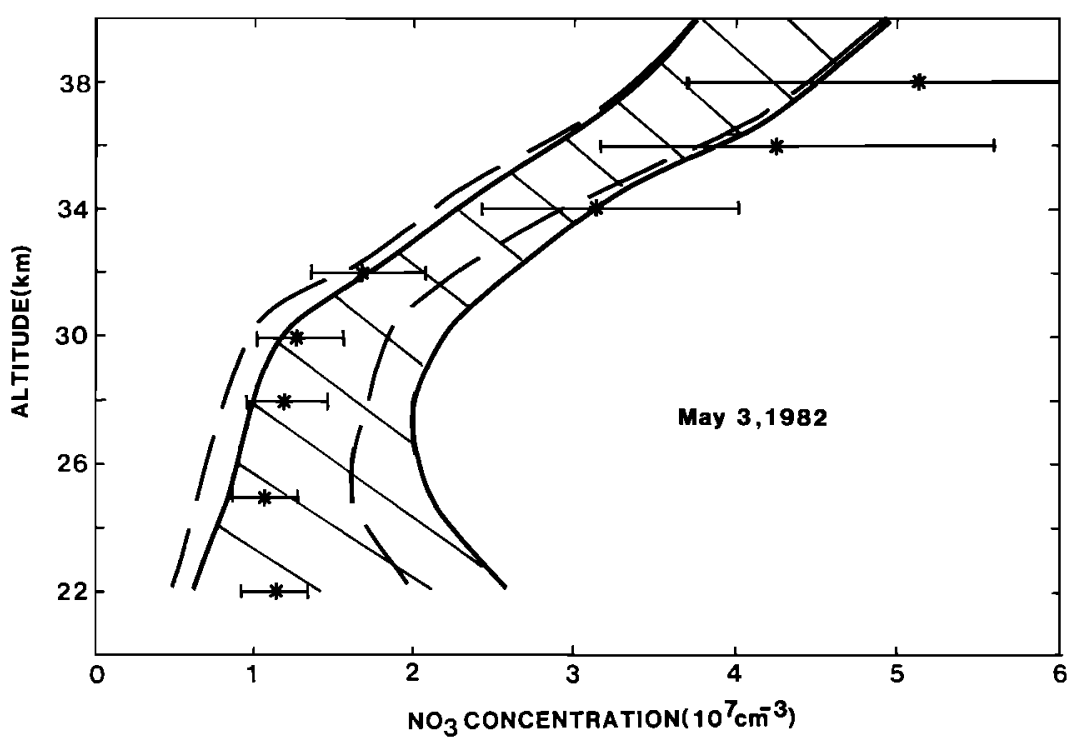

Fig. 5. Same as Figure 3, except for May 3, 1982, at 0330 LT.

of the scavenger would be the most important when the air parcels had reached the highest latitudes a few days before arriving at mid-latitude. This assumption is not confirmed by our results. Indeed, the air parcels had reached $55^{\circ} \mathrm{N}$ in September 1980 and $65^{\circ} \mathrm{N}$ in September 1981 [Norton and Noxon, 1986]. In this latter case the discrepancy would therefore have been more important than in September 1980. As shown in Figure 4, this is not the case, at least above 30 $\mathrm{km}$. In other respects it is clear from our results that the large reductions of $\left|\mathrm{NO}_{3}\right|$, observed occasionally by Norton and Noxon [1986], were not observed during the five balloon flights. This may be explained by the different experimental conditions and because only a lımited range of geophysical conditions were covered by our observations. More balloon flights are therefore needed, especially at higher latitudes, to try to confirm this effect of $\left|\mathrm{NO}_{3}\right|$ reduction.

Ravishankara and Mauldin [1986] and Sander [1986] claim that the $\mathrm{NO}_{3}$ absorption cross sections are temperature- dependent. Such a dependence is not confirmed by Cantrell et al. [1987]. The experimental results given by Naudet et al. [this issue] (Figures 3-7) have been obtained using the temperature-independent cross sections suggested by Cantrell et al. [1987]. Figures 3-7 also show the experimental results obtained with the cross sections given by Ravishankura and Mauldin [1986] and A. R. Ravishankara (private communication, 1987). On Figures 3-7 the experimental results were recalculated to correct the results given by Naudet et al. [this issue]. The correction is crude, assuming that $\left|\mathrm{NO}_{3}\right|$ is simply proportional to the inverse of the absorption cross sections available at the tangent point. A complete retrieval of the concentrations would be necessary to compute the concentrations accurately, since temperature changes along the optical paths. Nevertheless, the results are good approximations of these concentrations because most of the absorption takes place close to this tangent point. The calculations and the measurements are still in

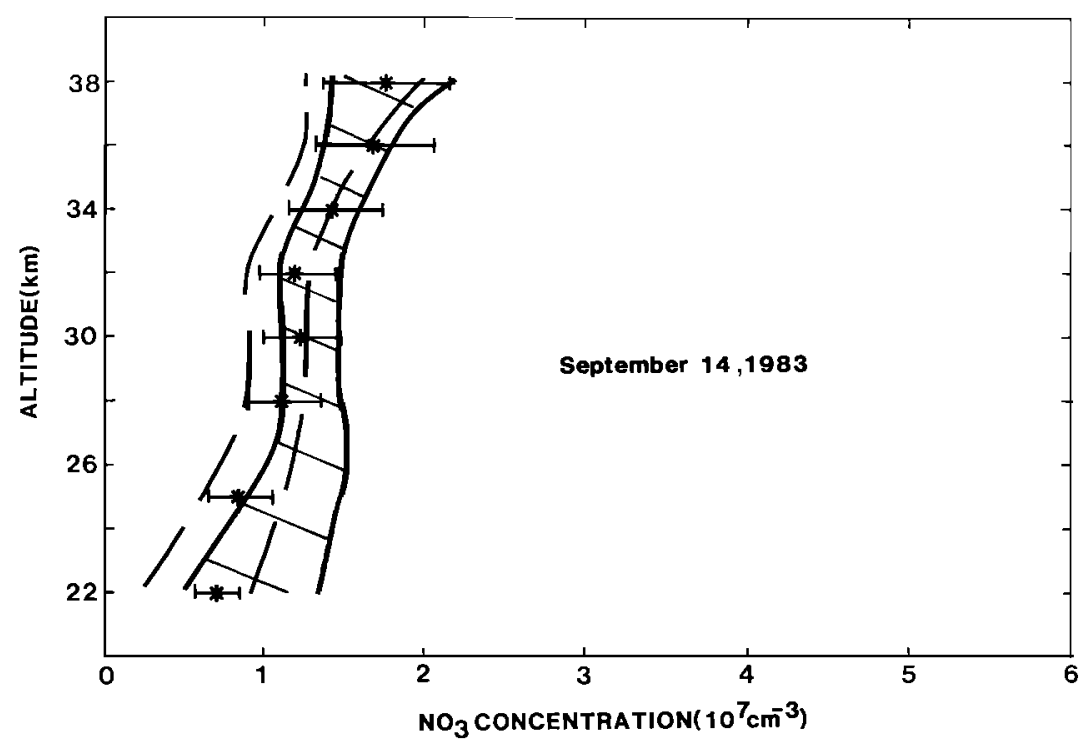

Fig. 6. Same as Figure 3, except for September 14, 1983, at 0330 LT. 


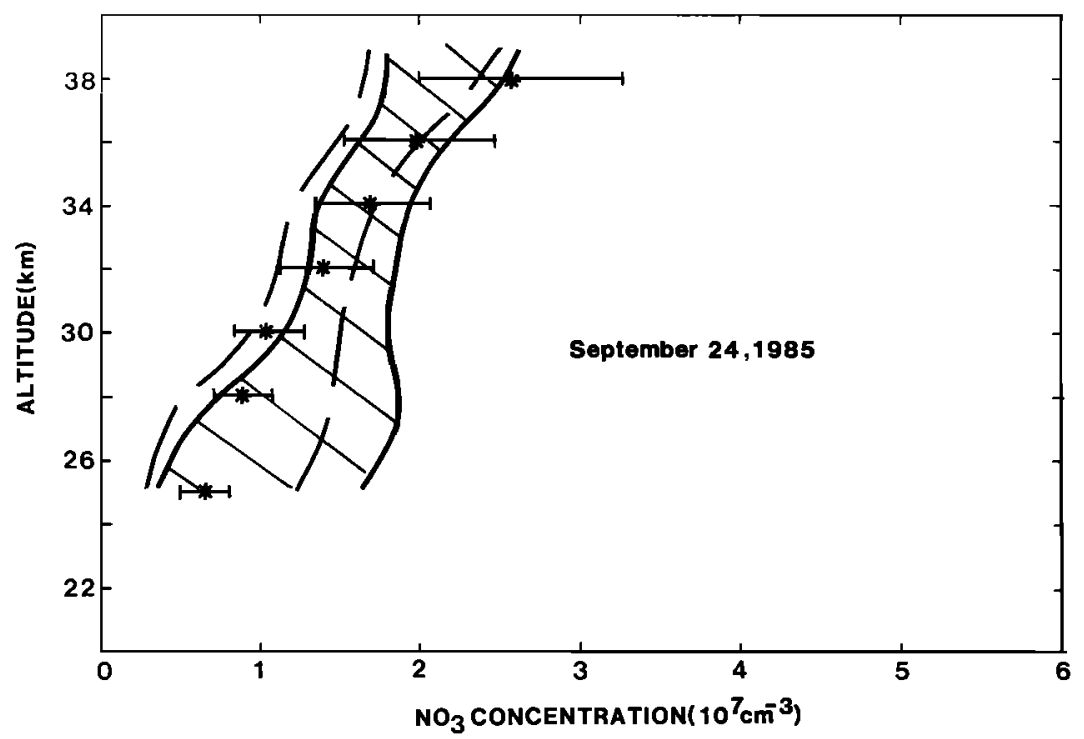

Fig. 7. Same as Figure 3, except for September 24, 1985, at 0315 LT.

good agreement. Therefore nothing may be drawn from our measurements concerning the temperature dependence of the $\left|\mathrm{NO}_{3}\right|$ absorption cross section.

\section{Conclusion}

The measurements of the vertical $\left|\mathrm{NO}_{3}\right|$ profile made by balloon above Aire-sur-l'Adour in the south of France between 1980 and 1985 have been compared with the results of a zero-dimensional model constrained by the ozone concentrations observed simultaneously with $\left|\mathrm{NO}_{3}\right|$ and by the temperature measured during the same period and at the same location. The main conclusion is that model and observations are in good agreement and, in particular, that the large concentrations observed in May are explained by the higher temperature measured in May than in September. No conclusion may be drawn from our measurements concerning the temperature dependence of the $\mathrm{NO}_{3}$ absorption cross sections. Our results do not need the existence of a large scavenging process of $\mathrm{NO}_{3}$, as reported by Norton and Noxon [1986], to be explained. Nevertheless, this does not deny Norton and Noxon's mechanism because the conditions of the experiments were not the same and because only a limited range of geophysical conditions was covered by our observations. Further balloon flight measurements are required, especially at higher latitudes and other seasons where the scavenger effect was found to be the strongest

Acknowledgments. Two of us (M. Pirre and R. Ramaroson) are very grateful to $D$. Carıolle for fruitful discussion concerning the model used in the calculations, which were made on the CIRCE at Orsay (France). We also thank R. Jenne, D. Joseph, and C. Craig from the National Center for Atmospheric Research, who provided us with the NMC temperature data, as well as J. C. Gille and G. Brasseur, for helpful discussions.

\section{REFERENCES}

Cantrell, C. A., J. A. Davidson, R. E. Schetter, B. A. Anderson, and $J$. G. Calvert, The temperature invariance of the $\mathrm{NO}_{3}$ absorption cross section in the $662 \mathrm{~nm}$ region, J. Phys. Chem. 91 . $5858,1987$.

DeMore, W. B., M. J. Molina, R. T. Watson, D. M. Golden, R. F. Hampson, M. J. Kurylo, C. J. Howard, and A. R. Ravishankara,
Chemical kinetics and photochemical data for use in stratospheric modeling, $J P L$ Publ., 83-62, 1983.

DeMore, W. B., D. M. Golden, R. F. Hampson, M. J. Kurylo, C. J. Howard, J. J. Margitan, M. J. Molina, and A. R. Ravishankara, Chemical kinetics and photochemical data for use in stratospheric modeling, Evaluation 7, JPL Publ., 85-37, 1985.

Hauchecorne, A., and M. L. Chanin, Density and temperature profiles obtained by lidar between 30 and $80 \mathrm{~km}$, Geophys. Res. Lett., 7, 565, 1980.

Herman, J. R., The problem of nighttime stratospheric $\mathrm{NO}_{3}, J$. Geophys. Res., 84, 6336, 1979.

Naudet, J. P., D. Huguenin. P. Rigaud, and D. Carıolle, Stratospheric observations of $\mathrm{NO}_{3}$ and its experimental and theoretical distribution between 20 and 40 km, Planet. Space Sci., 29, 707, 1981

Naudet, J. P., P. Rigaud, M. Pırre, and D. Huguenin, Altitude distribution of stratospheric $\mathrm{NO}_{3}, 1$, Observations of $\mathrm{NO}_{3}$ and related species, $J$. Geophys. Res., this issue.

Nicolet, M., Etude des reactions chimiques de l'ozone dans la stratosphere, 536 pp., Inst. R. Meteorol. de Belg., Brussels, Belgium, 1978.

Norton, R. B., and J. F. Noxon, Dependence of stratospheric $\mathrm{NO}_{3}$ upon latitude and season, J. Geophys. Res., 9/, 5323, 1986.

Ramaroson, R., M. Pirre, and D. Cariolle, A method adapted to the new generation of supercomputers to model the diurnal variations of the constituents in the middle atmosphere, Terra Cognita, 7. $560,1987$.

Ravishankara, A. R., and R. L. Mauldin III, Temperature dependence of the $\mathrm{NO}_{3}$ cross section in the 662-nm region, J. Geophys. Res., 91. 8709, 1986.

Sander, S. P, Temperature dependence of the $\mathrm{NO}_{3}$ absorption spectrum, J. Phys. Chem., 90, 4135, 1986.

Sanders, R. W., S. Solomon, G. H. Mount, M. W. Bates, and A. L. Schmeltekopf, Visible spectroscopy at McMurdo Station, Antarctica, 3, Observations of $\mathrm{NO}_{3}$, J. Geophys. Res., 92, 8339, 1987.

World Meteorological Organization, Atmospheric ozone 1985, Rep. 16, Geneva, Switzerland, 1985.

J.-P. Naudet, M. Pirre, R. Ramaroson, P. Rigaud, Laboratoire de Physique et Chimie de l'Environnement, CNRS, 3A, Avenue de la Recherche Scientifique, 45071 Orleans Cedex 2, France.

(Received May 10, 1988; revised January 25, 1989; accepted January $25,1989$. ) 